\title{
Effect of Dietary Supplementation of Ginger and Cinnamon on Growth Performance and Economics of Broiler Production
}

\author{
D.S. Gaikwad ${ }^{1,2} *$, Y.G. Fulpagare ${ }^{2}$, U.Y. Bhoite ${ }^{2}$, D.K. Deokar ${ }^{2}$ and C.A. Nimbalkar ${ }^{2}$ \\ ${ }^{1}$ Lovely Professional University, G.T. Road Phagwara, Punjab 144411, India \\ ${ }^{2}$ Department of Animal Husbandry and Dairy Science, PGI, Mahatma Phule Krishi \\ Vidyapeeth, Rahuri- 413722 (M.S)-India \\ *Corresponding author
}

\begin{abstract}
A B S T R A C T
The 140 day old 'Vencob-400' chicks, which were divided into seven treatment groups with four replicates per group (Five chicks per replicate) i.e. 20 chicks per treatment

groups. Dietary treatments consisted of basal diet $\mathrm{T}_{0}$ (Control), $\mathrm{T}_{1}, \mathrm{~T}_{2}$ and $\mathrm{T}_{3}$ with $\mathrm{T}_{4}, \mathrm{~T}_{5}$ and $\mathrm{T}_{6}$ consist of 1,2 and 3 per cent cinnamon while 1,2 and 3 per cent ginger, respectively. Body weight and feed consumption were recorded at weekly interval. Feed conversion ratio, dressing percentage, economics of broiler production were calculated. Cinnamon and ginger feeding were done separately and compared by completely randomized design (CRD). The body weight of the $2.0 \%\left(\mathrm{~T}_{2}\right)$ cinnamon and $1 \%$ ginger $\left(\mathrm{T}_{4}\right)$ group was significantly $(\mathrm{P} \leq 0.05)$ higher than the other groups. The average feed consumption was significantly highest $(3966.85 \mathrm{~g} / \mathrm{b})$ in control group and lowest $(3793.30$ $\pm 05.94 \mathrm{~g} / \mathrm{b})$ in $2.0 \%$ cinnamon $\left(\mathrm{T}_{2}\right)$ supplemented group. No mortality was observed entire experiment. Highest profit per bird was observed in $\mathrm{T}_{4}$ (Rs. 24.17) followed by $\mathrm{T}_{2}$ (21.15), $\mathrm{T}_{1}$ (18.27) and other treatments while lowest in $\mathrm{T}_{3}$ (8.47). Similarly highest cost benefit ratio was found in $\mathrm{T}_{4}$ supplemented with $1 \%$ ginger powder followed by $\mathrm{T}_{2}, \mathrm{~T}_{1}, \mathrm{~T}_{5}$, $\mathrm{T}_{0}, \mathrm{~T}_{3}$ and $\mathrm{T}_{6}$. From the result of present study it was concluded that dietary inclusion of $2.0 \%$ cinnamon and $1.0 \%$ ginger can be used as growth promoters for more profit per bird.
\end{abstract}

Keywords

Broiler, Cinnamon,

Ginger,

Supplementation,

Production,

Economics

Article Info

Accepted:

15 February 2019

Available Online:

10 March 2019

\section{Introduction}

India is the fourth-largest chicken producer in the world after China, Brazil and the USA. The consumption of chicken meat in India increased from $400 \mathrm{~g}$. per annum, to $2.5 \mathrm{~kg}$ per annum in the last five years (Poultry Sector, 2017). Poultry ration (feed) is important and major component of poultry farming, because of $80 \%$ cost only for procurement of feed
(Asghar et al., 2003). In the past, antibiotics were the most routinely used feed additives in poultry ration. Antibiotics is not only limited but their use in livestock and poultry industry also have been banned in many countries due to the reasons like alteration of natural gut microbiota and drug resistance As a result, to replace them without affecting the performance of poultry birds, natural growth promoters such as prebiotics, probiotics, 
synbiotics, enzymes, plant extracts and natural medicinal products etc., can be used in poultry ration (Borazjanizadeh et al., 2011).

Ginger and cinnamon are natural growth promoters and can be potential alternatives for common artificial growth promoters like antibiotics (Demir et al., 2003). Ginger is the rhizome of the plant Zingiber officinale, consumed as a delicacy, medicine or spice. Preliminary research indicates that nine compounds found in ginger may bind to serotonin receptors which may influence gastrointestinal function. Research conducted in-vitro shows that ginger extract might control the quantity of free radicals and the peroxidation of lipids (Al-Amin et al., 2006) and have anti-diabetic properties (Morakinyo et al., 2011).

Cinnamon (Cinnamomum cassia) commonly known as "dalchini" is important medicinal plants and widely used in India. It belongs to the Lauracea family and is native of Sri Lanka and South India (Jakhetia et al., 2010). Cinnamons possess appetite and digestion stimulant properties (Taback et al., 1999). Many essential oils have been extracted from the cinnamon like cinnamic acid, cinnamaldehyde, cinnamate, caryophyllene oxide, eugenol and L-borneol (Tung et al., 2008). Cinnamaldehyde having antibacterial (Chang et al., 2001), antioxidant properties (Singh et al., 2007) and other medicinal properties like antiulcer, anti-diabetic, antiinflammatory which have recently been reviewed by Jakhetia et al., (2010). Considerable attention has been paid to the role of nutritional manipulation in minimizing the total feed cost of production, increasing weights, dressing percentage, feed conversion and economics of broiler production. Keeping the above information in view, the present study was conducted on broilers with the following objectives, i) Study the effect of ginger and cinnamon supplementation on feed intake and feed conservation ratio in broilers.

ii) Study the growth performance of broilers.

iii) Study the economics of broiler production.

\section{Materials and Methods}

The trial was conducted on 140 day old, Vencobb-400 broiler chicks at Poultry Unit, Veterinary Polyclinic and AI Center MPKV, Rahuri-413 722, Dist. Ahmednagar, Maharashtra. The cinnamon and ginger powder was procured from local market. The 140 birds were divided in to 7 treatment group with four replicates of 5 chicks each and housed under deep litter system. The $\mathrm{T}_{0}$ birds were fed on a basal ration (Control), $\mathrm{T}_{1}$ Basal ration $+1 \%$ Cinnamon (i.e. $10 \mathrm{~g} / \mathrm{kg}$ of feed), $\mathrm{T} 2$ Basal ration $+2 \%$ Cinnamon powder (i.e. $20 \mathrm{~g} / \mathrm{kg}$ of feed), $\mathrm{T}_{3}$ Basal ration $+3 \%$ Cinnamon powder (i.e. $30 \mathrm{~g} / \mathrm{kg}$ of feed), $\mathrm{T}_{4}$ Basal ration $+1 \%$ Ginger powder (i.e. 10 $\mathrm{g} / \mathrm{kg}$ of feed), $\mathrm{T}_{5}$ Basal ration $+2 \%$ Ginger powder (i.e. $20 \mathrm{~g} / \mathrm{kg}$ of feed) and $\mathrm{T}_{6}$ Basal ration $+3 \%$ Ginger powder (i.e. $30 \mathrm{~g} / \mathrm{kg}$ of feed). Immediately arrival of chicks were weighed and distributed randomly in to 7 treatment groups viz, $\mathrm{T}_{0}, \mathrm{~T}_{1}, \mathrm{~T}_{2}$ and $\mathrm{T}_{3}, \mathrm{~T}_{4}, \mathrm{~T}_{5}$ and $\mathrm{T}_{6}$ with 20 chicks in each group, on body weight basis.

Body weight and feed consumption were recorded at weekly interval up to $6^{\text {th }}$ weeks of age. Feed conversion efficiency was estimated as quantity $(\mathrm{kg})$ of feed consumed for every $\mathrm{kg}$ gain in body weight. Performance efficiency (\%) was calculated as the ratio of body weight $(\mathrm{kg})$ and feed conversion efficiency $(\mathrm{kg})$, multiplied by 100 . At the end of trial, three birds from each group were randomly selected and slaughtered for estimating dressing percentage. The economics of broiler production was worked out by considering the total cost of production which included the feed cost, chicks, labour, medicines, vaccines and the overhead costs. Proximate composition of broiler ration and feed 
additives analysis was carried out as per the method given in A.O.A.C., 2005.The data were analyzed by standard statistical techniques (Snedecor and Cochran, 1994).

\section{Results and Discussion}

The data pertaining to growth performance and allied traits as influenced by dietary cinnamon and ginger supplementation in broiler chickens are elucidated here under.

\section{Chemical composition of experimental feed ingredients (\% DM basis)}

The experimental feeds viz. broiler starter and finisher which were supplemented with cinnamon and ginger powder as per treatment details. The proximate composition of the rations is presented in Table 1.

\section{Starter ration}

The crude protein, crude fiber, ether extract, total ash, nitrogen free extract and acid insoluble ash of starter ration were 23.00, $4.60,4.80,7.20,60.40$ and 1.25 per cent respectively and calculated metabolizable energy (ME) of the diet was 2863.811 $\mathrm{Kcal} / \mathrm{kg}$.

\section{Finisher ration}

The crude protein, crude fiber, ether extract, total ash, nitrogen free extract and acid insoluble ash of finisher ration were 20.00, $3.78,4.30,6.85,65.15$ and 1.44 per cent respectively and calculated metabolizable energy (ME) of the diet was $2939.75 \mathrm{Kcal} / \mathrm{kg}$.

\section{Proximate composition of feed additives}

Composition of Ginger powder observed in the present investigation was in agreement with Najafi and Taherpour et al., (2014) who reported that composition of ginger was 91.00, $10.20,18.30,3.20,4.90$ and 54.60 per cent of dry matter, crude protein, crude fiber, ether extract, ash and nitrogen free extract, respectively. Composition of cinnamon powder observed in the present investigation was similar to that reported by Najafi and Taherpour et al., (2014) as 92.50, 4.10, 45.30, $1.70,4.40$ and 37.00 per cent of dry matter, crude protein, crude fiber, ether extract, ash and nitrogen free extract, respectively. Ademola, et al., (2009) reported that composition of ginger was 87.39, 1.35, 5.85, $2.93,2.29$ and 87.58 per cent of dry matter, ether extract, crude protein, crude fiber, ash and nitrogen free extract, respectively.

\section{Body weight changes (g)}

The data on body weight is presented in Table 2 , which indicate the highest live weight $(\mathrm{g})$ was obtained in $\mathrm{T}_{2}(2408.5 \pm 22)$ followed by $\mathrm{T}_{4}(2376.75 \pm 25.26), \mathrm{T}_{5}(2326.20 \pm 24.13), \mathrm{T}_{6}$ $(2300.4 \pm 25.81), \mathrm{T}_{1}(2300.08 \pm 23.19), \mathrm{T}_{3}$ $(2290.05 \pm 26.89)$ and $\mathrm{T}_{0}(2169.05 \pm 11.18)$ treatments. The zero days average live weights of each treatment were comparable. The final body weight of birds was significantly $(\mathrm{P} \leq 0.05)$ higher in all supplemented treatment groups in comparison to control. This result was in line with the finding of Sang-oh et al., (2013) who reported that, the body weight of the cinnamon powder groups were increased significantly $(\mathrm{P}<0.05)$ when compared to the control group. Farinu et al., (2004) also reported that supplementation of ginger at the levels of 5,10 , or $15 \mathrm{~g} / \mathrm{kg}$ of feed slightly improved growth in broilers. In constant, ElDeek et al., (2002) observed that a diet containing ginger at the rate of $1 \mathrm{~g} / \mathrm{kg}$ of feed did not affect growth performance.

\section{Body weight gain (g)}

The data on body weight (Table 3) that average gain in body weight in treatment $\mathrm{T}_{4}$ $(633.60 \pm 32.53 \mathrm{~g})$ group was significantly $(\mathrm{P} \leq 0.05)$ higher over other treatments. Then followed by $\mathrm{T}_{6}(563.90 \pm 27.00 \mathrm{~g}), \mathrm{T}_{3}(542.45$ 
$\pm 33.00 \mathrm{~g}), \mathrm{T}_{2}\left(501.85 \pm 32.06, \mathrm{~T}_{0}(499.18 \pm\right.$ $18.51 \mathrm{~g}), \mathrm{T}_{1}\left(476.98 \pm 25.56\right.$ and $\mathrm{T}_{5}(476.70 \pm$ 25.23). Sang et al., (2013) who concluded that cinnamon treated birds had higher body weight gain. Najafi and Taherpour (2014) showed the dietary ginger inclusion leads to significantly $(\mathrm{P}<0.05)$ higher body weight gain.

\section{Cumulative feed consumption (g)}

The cumulative feed intake (Table 5) was significantly $(\mathrm{P} \leq 0.05)$ improved from $21^{\text {st }}$ day of age. It was evident from the table that average feed consumption vary significantly $(\mathrm{P} \leq 0.05)$ from control group. However, it was observed that either the cinnamon or ginger powder supplementation from 1, 2 and $3 \%$, in both the supplements the feed intake was significantly less at $2.0 \%\left(\mathrm{~T}_{2}\right.$ and $\left.\mathrm{T}_{5}\right)$. Present findings were in agreement with, Arshad et al., (2012) who concluded that addition of ginger extract in poultry diet reduced the feed intake. Barazesh et al., (2013) reported that the effect of herb ginger powder on increasing levels of dietary herb ginger powder caused a significant reduction in feed consumption.

\section{Feed efficiency}

It was evident from the table 5 that treatment T0 (1.87 \pm 0.01$)$ showed lowest feed efficiency level whereas, T4 (1.65 \pm 0.02$)$ showed the highest. Data in table 5 indicated that supplementation of $1.0 \%$ ginger powder in broilers diet was significantly superior to rest of the treatments. The findings of present study were in accordance with results reported by Kausar et al., (1999) and Moorthy et al., (2009), Najafi and Taherpour (2014).

\section{Dressing percentage}

The average dressing percentage (Table 4) among the different treatments groups varied between $77.04 \pm 0.02$ to $78.69 \pm 0.08$ per cent. The differences among all the treatment groups were found significant $(\mathrm{P} \leq 0.05)$.

Table.1 Per cent chemical composition of experimental broiler ration on dry matter basis

\begin{tabular}{|l|c|c|}
\hline \multirow{2}{*}{\multicolumn{1}{c|}{ Nutrients }} & \multicolumn{2}{|c|}{ Broiler ration } \\
\hline Crude protein & Starter & Finisher \\
\hline Crude fiber & 23.00 & 20.00 \\
\hline Ether extract & 4.60 & 3.78 \\
\hline Total ash & 4.80 & 4.30 \\
\hline Nitrogen free extract & 7.20 & 6.85 \\
\hline Acid insoluble ash & 60.40 & 65.15 \\
\hline ME (Kcal/kg) & 1.25 & 1.44 \\
\hline
\end{tabular}

Table.2 Proximate composition (\%) of experimental feed additives on dry matter basis

\begin{tabular}{|l|c|c|c|c|c|c|}
\hline \multicolumn{1}{|c|}{$\begin{array}{c}\text { Plant } \\
\text { Products }\end{array}$} & DM & CP & CF & EE & Ash & NFE \\
\hline Ginger & 89.00 & 9.20 & 17.30 & 3.00 & 4.10 & 66.40 \\
\hline Cinnamon & 91.50 & 3.90 & 45.20 & 1.80 & 4.30 & 44.80 \\
\hline
\end{tabular}


Table.3 Broilers traits in different groups of chicks up to 6th weeks of age

\begin{tabular}{|c|c|c|c|c|}
\hline Treat & Body Weight & Weight Gain & Feed Intake & FCR \\
& & & & \\
\hline $\mathbf{T}_{\mathbf{0}}$ & $2169.05^{\mathrm{a}}$ & $499.18^{\mathrm{a}}$ & $3966.85^{\mathrm{c}}$ & $1.87^{\mathrm{c}}$ \\
& \pm 11.18 & \pm 18.51 & \pm 15.01 & \pm 0.01 \\
\hline $\mathbf{T}_{\mathbf{1}}$ & $2300.08^{\mathrm{b}}$ & $476.98^{\mathrm{a}}$ & $3849.05^{\mathrm{b}}$ & $1.75^{\mathrm{ab}}$ \\
& \pm 23.19 & \pm 25.56 & \pm 13.33 & \pm 0.02 \\
\hline $\mathbf{T}_{\mathbf{2}}$ & $2408.50^{\mathrm{d}}$ & $501.85^{\mathrm{a}}$ & $3793.30^{\mathrm{a}}$ & $1.71^{\mathrm{b}}$ \\
& \pm 22.00 & \pm 32.06 & \pm 05.94 & \pm 0.04 \\
\hline $\mathbf{T}_{\mathbf{3}}$ & $2290.05^{\mathrm{b}}$ & $542.45^{\mathrm{a}}$ & $3804.40^{\mathrm{a}}$ & $1.72^{\mathrm{ab}}$ \\
& \pm 26.89 & \pm 33.00 & \pm 05.64 & \pm 0.02 \\
\hline $\mathbf{T}_{\mathbf{4}}$ & $2376.75^{\mathrm{cd}}$ & $633.60^{\mathrm{b}}$ & $3842.45^{\mathrm{b}}$ & $1.65^{\mathrm{a}}$ \\
& \pm 25.26 & \pm 32.53 & \pm 10.25 & \pm 0.02 \\
\hline $\mathbf{T}_{\mathbf{5}}$ & $2326.20^{\mathrm{bc}}$ & $476.70^{\mathrm{a}}$ & $3809.35^{\mathrm{a}}$ & $1.67^{\mathrm{a}}$ \\
\hline $\mathbf{T}_{\mathbf{6}}$ & \pm 24.13 & \pm 25.23 & \pm 09.74 & \pm 0.02 \\
\hline $\mathbf{M e a n}$ & $2300.40^{\mathrm{b}}$ & $563.90^{\mathrm{ab}}$ & $3860.10^{\mathrm{b}}$ & $1.72^{\mathrm{ab}}$ \\
& \pm 25.81 & \pm 27.00 & \pm 11.44 & \pm 0.02 \\
\hline
\end{tabular}

Values bearing different superscripts in column differ significantly $(\mathrm{P} \leq 0.05)$

Table.4 Effect of supplementation cinnamon and ginger on dressing percentage (without skin)

\begin{tabular}{|c|c|}
\hline Treatment & Mean Dressing Percentage \\
\hline $\mathbf{T}_{\mathbf{0}}$ & $77.04 \pm 0.02^{\mathrm{a}}$ \\
\hline $\mathbf{T}_{\mathbf{1}}$ & $78.36 \pm 0.39^{\mathrm{d}}$ \\
\hline $\mathbf{T}_{\mathbf{2}}$ & $78.66 \pm 0.17^{\mathrm{cd}}$ \\
\hline $\mathbf{T}_{\mathbf{3}}$ & $77.40 \pm 0.09^{\mathrm{ab}}$ \\
\hline $\mathbf{T}_{\mathbf{4}}$ & $78.69 \pm 0.08^{\mathrm{c}}$ \\
\hline $\mathbf{T}_{\mathbf{5}}$ & $78.12 \pm 0.01^{\mathrm{d}}$ \\
\hline $\mathbf{T}_{\mathbf{6}}$ & $77.90 \pm 0.04^{\mathrm{bc}}$ \\
\hline
\end{tabular}

Values bearing different superscripts in column differ significantly $(\mathrm{P} \leq 0.05)$ 
Table.5 Effect of supplementation of cinnamon and ginger on weekly cumulative feed consumption $(\mathrm{g})$

\begin{tabular}{|c|c|c|c|c|c|c|c|c|}
\hline Sr. No. & Particulars & $\mathbf{T}_{\mathbf{0}}$ & $\mathbf{T}_{1}$ & $\mathbf{T}_{2}$ & $\mathbf{T}_{3}$ & $\mathbf{T}_{4}$ & $\mathbf{T}_{5}$ & $\mathbf{T}_{6}$ \\
\hline 1. & Cost of day old chick (Rs.) & 18 & 18 & 18 & 18 & 18 & 18 & 18 \\
\hline 2. & Cost of feed (Rs/kg) & 27 & 27 & 27 & 27 & 27 & 27 & 27 \\
\hline 3. & $\begin{array}{l}\text { Cost of Ginger and Cinnamon } \\
\text { Powder (Rs/Bird) }\end{array}$ & 0.00 & 1.38 & 2.89 & 4.12 & 1.18 & 2.32 & 3.45 \\
\hline 4. & Total cost of feed (Rs/kg) & 27 & 28.38 & 29.89 & 31.12 & 28.18 & 29.32 & 30.45 \\
\hline 5. & $\begin{array}{l}\text { Average total feed consumed } \\
\text { per bird }(\mathrm{Kg})\end{array}$ & 3.966 & 3.849 & 3.793 & 3.804 & 3.842 & 3.809 & 3.86 \\
\hline 6. & $\begin{array}{l}\text { Cost of feed consumed per bird } \\
\text { (Rs.) }\end{array}$ & 107.9 & 109.2 & 113.4 & 118.4 & 108.3 & 111.7 & 117.5 \\
\hline 7. & $\begin{array}{l}\text { Average body weight at the end } \\
\text { of } 6^{\text {th }} \text { week }(\mathrm{Kg})\end{array}$ & 2.169 & 2.300 & 2.408 & 2.290 & 2.376 & 2.326 & 2.300 \\
\hline 8. & $\begin{array}{l}\text { Feed consumption per kg live } \\
\text { weight gain }(\mathrm{Kg})\end{array}$ & 1.828 & 1.673 & 1.575 & 1.661 & 1.617 & 1.638 & 1.678 \\
\hline 9. & $\begin{array}{l}\text { Cost of feed per kg live weight } \\
\text { gain (Rs.) }\end{array}$ & 49.36 & 47.49 & 47.08 & 51.69 & 45.57 & 48.01 & 51.10 \\
\hline 10. & Rearing Cost per bird (Rs.) & 4 & 4 & 4 & 4 & 4 & 4 & 4 \\
\hline 11. & $\begin{array}{l}\text { Total cost of production (Rs.) } \\
(1+6+10)\end{array}$ & 129.9 & 131.2 & 135.4 & 140.4 & 130.3 & 133.7 & 139.5 \\
\hline 12. & $\begin{array}{l}\text { Average price realized @ Rs. } \\
65 \text { per kg live weight (Rs.) }\end{array}$ & 140.99 & 149.5 & 156.52 & 148.85 & 154.44 & 151.19 & 149.5 \\
\hline 13. & Net profit per bird (Rs.) (12-11) & 11.09 & 18.27 & 21.15 & 8.47 & 24.17 & 17.51 & 9.96 \\
\hline 14 & Cost benefit ratio & 1.09 & 1.14 & 1.16 & 1.06 & 1.19 & 1.13 & 1.07 \\
\hline
\end{tabular}

Values bearing different superscripts in column differ significantly $(\mathrm{P} \leq 0.05)$

Fig.1 Effect of cinnamon and ginger on cost benefit ratio at the end of experiment

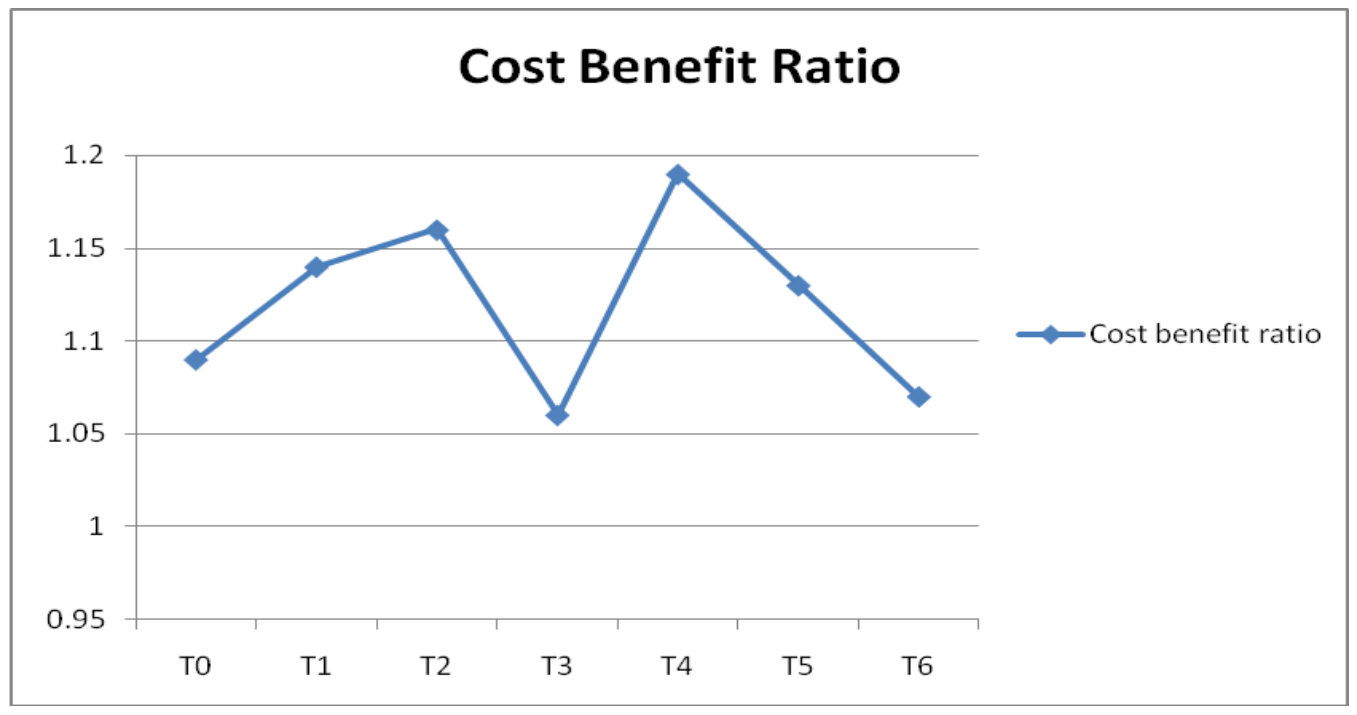


Highest dressing percentage was recorded in the treatments $\mathrm{T}_{4}(78.69 \pm 0.08)$ and $\mathrm{T}_{2}(78.66$ $\pm 0.17)$ which were at par to each other. Herawati and Marjuki (2011) showed broilers given ration with red ginger showed significantly higher dressed weight $(\mathrm{P} \leq 0.05)$. Park et al., (2013) observed that the dressing percentage were significantly higher in the CNP (Cinnamon powder) groups than the control group (77.08).

\section{Economics of broiler production}

The cost of feed (Table 3 ) in $T_{1}, T_{2}, T_{3}, T_{4}, T_{5}$ and $\mathrm{T}_{6}$ increased in accordance with the level of addition of cinnamon powder and ginger powder. Moreover, broilers in treatment groups $\mathrm{T}_{2}$ gained highest body weight $(2408.50 \pm 22.00 \mathrm{~g})$ with feed cost of Rs. 113.40 and lowest in T0 (control) group gained weight $(2169.05 \pm 11.18 \mathrm{~g})$ with feed cost Rs. 107.90 (Fig. 1). Present findings are in agreement with, Ahmed et al., (2006); Mohamed and Yusuf (2011); Arshad et al., (2012); Elmakki et al., (2013); Hossain et al., (2014; Oleforuth-okoleh et al., (2014) reported that increased economic efficiency of broilers diet supplemented with ginger. The highest cost benefit ratio was found in $\mathrm{T}_{4}$ supplemented with $1 \%$ ginger powder followed by $\mathrm{T}_{2}, \mathrm{~T}_{1}, \mathrm{~T}_{5}, \mathrm{~T}_{0}, \mathrm{~T}_{3}$ and $\mathrm{T}_{6}$.

In conclusion, the effect of dietary supplementation of ginger (Zingiber officinale) and cinnamon (Cinnamomum zeylanicum) on growth performance indicated that $2.00 \%$ of cinnamon powder or $1.00 \%$ of ginger powder had significantly higher body weight and weekly gain in body weight along with better feed conversion. Highest dressing percentage in $T_{4}$ and $T_{2}$ group as compare to other treatment group. The highest cost benefit ratio was found in $\mathrm{T}_{4}$ supplemented with $1 \%$ ginger powder as compared to other treatment groups and control. Hence, it was concluded that inclusion of $2 \%$ cinnamon and $1.0 \%$ ginger can be used as growth promoters.

\section{References}

Ademola, S.G., Farinu, G.O., Babatunde, G. M., (2009). Serum lipid, growth and hematological parameters of broilers fed Garlic, Ginger and their mixtures. World J. Agric. Sci. 5(1):99-104.

Ahmed, M.R.O., Hala, M., Wahed, A.E. and Mona, S.R. (2006). Performance and carcass characteristics of broiler chicks fed diets supplemented with some medicinal and aromatic plants. Poult. Sci. 85, 1128-1132.

Al-Amin ZM, Thomson M, Al-Qattan KK, Peltonen-Shalaby R, Ali M. (2006). Anti-diabetic and hypolipidaemic properties of ginger (Zingiber officinale) in streptozotocin-induced diabetic rats. Br J. Nutr. 96(4), 660-666.

AOAC (2005). Association of Official Analytical Chemists. Official Method of Analysis. Washington, DC.

Arshad, M., Kakar, A.H., Durrani, F.R., Akhtar, A., Shakirullah, S., Niamatullah, M. (2012). Impact of Ginger (Z. Economical and immunological officinale) extract on broiler chicks. Pakistan J. Sci. 64(1), 46-48.

Asghar, A., Farooq, M., Mian, M.A., Khurshid, A. (2003). Economics of broiler production of Mardan division. J. Rural Dev. 32(3), 56-65.

Barazesh, H., Mohammad B. P., Somaye, S., Tahereh M. A. (2013). The effect of ginger powder on performance, carcass characteristics and blood parameters of broilers. Int. J. Adv. Bio. and Biomedical Res. 1(12), 1645-1651.

Borazjanizadeh, M., Eslami, M., M, Chaji M., Fayazi, J. (2011). The effect of clove and oregano on economic value of broiler chickens diet under hot weather of Khuzesta. J. Anim. Vet. Adv. 10(2), 169-173.

Chang, S.T., Chen, P.F., Chang, S.C. (2001). 
Antibacterial Activity of Leaf Essential Oils and Their constituents from Cinnamomum osmophloeum. J. of Ethno pharmacology. 77, 123-127.

Daghir, N.J. (2009). Nutritional Strategies to Reduce Heat Stress in Broilers and Broiler Breeders. Lohaman Information. 44(1), 6.

Demir, E., Sarica, S., Ozcan, M.A, Suicmez, M. (2003). The use of natural feed additives as alternatives for an antibiotic growth promoter in broiler diets. Br. J. Poult. Sci. (44), 44-45.

El-Deek, A.A., Attia, Y.A., Maysa, M., Hannfy, M. (2002). Effect of anise (Pimpinella anisum), ginger (Zingiber officinale Roscoe) and fennel (Foeniculum vulgare) and their mixture on performance of broilers. Arch. Geflügelkd. 67, 92-96.

Elmakki, A. M., AbdelAtti A. K, Dousa M. B., Elagib A. A. H., Malik E. E. H, and Elamin M. K. (2013). Effect of Treated Cowpea Seeds on Broiler Chicken. Global Journal of Animal Scientific Research. 1(1), 76-83.

Farinu, G.O., Ademola, S.G., Ajayi Obe, A.O., Babatunde, G.M. (2004). Growth, haematological and biochemical studies on garlic and ginger-fed broiler chickens. Moor J. Agric. Res. 5, 122 128 .

Hashemi S.R., Davoodi, H. (2010). Phytogenics as New Class of Feed Additive in Poultry Industry. J.Ani.Vet. Adv. 9, 2295-2304.

Herawati and Marjuki (2011). The Effect of Feeding Red Ginger (Zingiber officinale Rosc.) as phytobiotic on Broiler Slaughter Weight and Meat Quality. Int. J. Poult. Sci. 10(12), 983-985.

Hossain, M.M. Howlader, A.J. Islam, M.N., Beg, M.A.H. (2014). Evaluation of locally available herbs and spices on physical, biochemical and economical parameters on broiler production. Inter.
J. Plant Ani. Environ. Sci. 4(1), 317323.

Jakhetia, V., Patel, R., Khatri, P., Pahuja, N., Garg, S., Pandey, A., Sharma, S. (2010). Cinnamon: a pharmacological review. J. Adv. Sci. Res. 1,19-23.

Kausar, R., Rizvi, F., Anjum, A.D. (1999). Effect of carminative mixture on health of broiler chicks. Pakistan J. Biol. Sci. 2(3), 1074-1077.

Mohammed, A. A., Yusuf, M. (2011). Evaluation of ginger (Zingiber officinale) as a feed additive in broiler diets. Livestock Research for Rural Development. Volume 23, Article \#202. http://www.lrrd.org/lrrd23/9/moha2320 2.htm.

Moorthy, M., Ravi, S., Ravi kumar, M., Viswanathan, K., Edwin, S.C. (2009). Ginger, Pepper and Curry Leaf powder as feed additives in broiler diet. Int. J. Poult. Sci. 8(8), 779-782.

Morakinyo A.O, Akindele A.J, Ahmed Z. 2011. Modulation of antioxidant enzymes and inflammatory cytokines: Possible mechanism of anti-diabetic effect of ginger extracts. Afr. J. Biomed. Res. 9, 195-202.

Najafi, S. and Taherpour, K. (2014). Effects of Dietary Ginger, Cinnamon, Synbiotic and Antibiotic supplementation on performance of broilers. J. Anim. Sci. Adv. 4(1), 658-667.

Oleforuh-Okoleh, V.U., Chukwu, G.C. and Adeolu, A.I. (2014). Effect of ground Ginger and Garlic on the growth performance, carcass quality and economics of production of broiler chickens. Global J. Bio. Sci. and Biotech. 3(3), 225-229.

Park, B.S. (2008). Effect of dietary cinnamon powder on savor and quality of chicken meat in broiler chickens. J. Korean Soc. Food Sci. Nutr. 37(5), 618-624.

Poultry Sector in India. 2017. https://www.rvo.nl/sites/default/files/20 
17/05/.

Sang-oh, P., Chae-Min, R., Byung-Sung, P. and Jong, H. (2013). The meat quality and growth performance in broiler chickens fed diet with cinnamon powder. J. Envi. Bio. 34, 127-133.

Singh, G., Maurya, S., Cesar, M.P., Catalan, A.M. (2007). A comparison of chemical, antioxidant and anti-microbial studies of cinnamon leaf and bark volatile oils, oleoresins and their constituents. Food and Chemical Toxicology. 45, 1650-1661.

Snedecor, G. W., Cochran, W. G. (1994).
Statistical methods ( $8^{\text {th }}$ Ed.). The Iowa state college perss, Ames, IOWA, Oxford and I. B. H. publication Co., Calcutta.

Taback, M., Armon, R., Neeman, I. (1999). Cinnamon extracts inhibitory effect on Hellcobater pylori. J. Ethnopharmacol. 67, 269-277.

Tung, Y.T., Chua, M.T., Wang, S.Y., Chang, S.T. (2008). Anti-inflammatory activities of essential oil and its constituents from indigenous cinnamon (Cinnamon osmophloeum) Twigs Bio resource Tech. 99, 3908-3913.

\section{How to cite this article:}

Gaikwad, D.S., Y.G. Fulpagare, U.Y. Bhoite, D.K. Deokar and Nimbalkar, C.A. 2019. Effect of Dietary Supplementation of Ginger and Cinnamon on Growth Performance and Economics of Broiler Production. Int.J.Curr.Microbiol.App.Sci. 8(03): 1849-1857. doi: https://doi.org/10.20546/ijcmas.2019.803.219 